\title{
PROBLEMY DEMOKRACJI I PARLAMENTARYZMU BULGARSKIEGO PO I WOJNIE ŚWIATOWEJ. MIĘDZY KONTYNUACJĄ POLITYCZNĄ A PRZEBUDOWĄ STRUKTUR
}

\author{
THE PROBLEMS OF BULGARIAN DEMOCRACY AND PARLIAMENTARISM \\ AFTER THE FIRST WORLD WAR. BETWEEN POLITICAL CONTINUATION \\ AND STRUCTURE RECONSTRUCTION
}

The article presents the process of deforming parliamentary democracy in Bulgaria after the First World War. The analysis begins with the presentation of fundamental political principles and relations between the main state institutions in the Tyrnovo Constitution, the fundamental law of Bulgaria in this period. Further, the problems of Bulgarian parliamentarism are discussed. Parliamentary democracy in Bulgaria in the interwar period was deformed by violating the rules of the parliament and subordinating it to party interests. It was further weakened by the usurpation of power (two coups d'état), disrespect for the constitutional principles, and by regulations prohibiting the activity of certain political forces. As a result, Bulgaria has evolved from a parliamentary monarchy that respecting the parliamentary system and procedures to the dictatorship.

Słowa kluczowe: konstytucja tyrnowska, system polityczny Bułgarii, autorytaryzm, zamach stanu

Key words: Tyrnovo Constitution, political system in Bulgaria, authoritarianism, coup d'état

* Dr Rafal Woźnica, Uniwersytet Jagielloński, Instytut Nauk Politycznych i Stosunków Międzynarodowych, rafal.woznica@uj.edu.pl, https://orcid.org/0000-0001-7623-4100

\section{UWAGI WSTEPPE}

R udowa współczesnego państwa bułgarskiego rozpoczęła się wraz z utworzeniem Księstwa Bułgarskiego i przyjęciem konstytucji tyrnowskiej w latach 1878-1879. Tworzony wówczas system polityczny — podobnie jak w przypadku innych państw bałkańskich — był determinowany przez szereg czynników, wśród których za najważniejsze należy uznać: tradycję państwowo-prawną i historyczną, zaangażowanie sił zewnętrznych w rozwiązywanie najważniejszych problemów, warunki społeczno-ekonomiczne oraz stosunek sił partyjno-politycznych w kraju. W przyjętej w 1879 r. konstytucji ustalono zasady życia politycznego Bułgarii na długie lata. Jednak w wyjątkowych warunkach panujących w Bułgarii po I wojnie światowej szczególnego znaczenia nabrała kwestia praktycznej realizacji przepisów konstytucji tyrnowskiej. W bułgarskiej historiografii istnieje przekonanie o znacznych rozbieżnościach między przepisami konstytucji a rzeczywistością polityczną Bułgarii w okresie między dwiema wojnami światowymi.

Zasadniczym celem badawczym autora opracowania jest ukazanie procesu deformowania demokracji parlamentarnej w Bułgarii po I wojnie światowej. Autor swoje 
rozważania rozpoczął od przedstawienia ogólnych zasad ustrojowych oraz relacji między organami władzy państwowej, zawartych w konstytucji tyrnowskiej, czyli w ustawie zasadniczej obowiązującej w Bułgarii w omawianym okresie, a następnie wskazał problemy parlamentaryzmu bułgarskiego, aż do zawieszenia obowiązującej konstytucji w $1934 \mathrm{r}$.

\section{ODRODZENIE BULGARSKIEJ SUWERENNOŚCI}

W porozumieniu zawartym między mocarstwami podczas kongresu berlińskiego przewidywano dalszy związek Bułgarii z imperium osmańskim. Traktatem berlińskim ustanowiono Księstwo Bułgarii (pozostające pod zwierzchnictwem imperium osmańskiego) oraz Rumelię Wschodnią (autonomiczną prowincję turecką), zamiast wielkiego księstwa bułgarskiego pierwotnie przewidzianego na mocy pokoju w San Stefano ${ }^{1}$. Mocarstwa narzuciły także ograniczenie w wyborze głowy państwa, którym był książę Bułgarii. Wyboru władcy dokonywała co prawda ludność, jednak konieczna była zgoda mocarstw oraz zatwierdzenie wyboru przez rząd osmański ${ }^{2}$ Światowe potęgi zachowały wszystkie przywileje gospodarcze i handlowe, nawet jeśli nie zawarły stosownych umów z Bułgarią (art. 8). Bułgarię zmuszono do płacenia daniny na rzecz sułtana, a także do zapewnienia swoim obywatelom pełnej wolności wyznania oraz równego traktowania wszystkich wspólnot religijnych. W wyniku decyzji podjętych w Berlinie Bułgaria została znacznie pomniejszona i mimo że znajdowała się formalnie pod zwierzchnictwem Turcji, uzyskała prawo do budowy własnego systemu politycznego ${ }^{3}$.

W praktyce jednak te przejawy ograniczenia suwerenności zostały przez Bułgarię ominięte i de facto zniesione. Na bułgarską niezależność największy wpływ miał rygor poddania się i respektowania traktatów zawartych między Turcją i wieloma krajami europejskimi, które również zostały nałożone na Księstwo Bułgarii. Umowy obowiązujące na terytorium całego imperium dawały liczne przywileje podatkowe i prawne, m.in. niską stawkę celną. Mimo nalegań strony bułgarskiej wielkie mocarstwa nie zgodziły się na rezygnację z tych uprawnień. Dopiero w 1907 r. te warunki zostały ograniczone, a całkowite ich zniesienie nastąpiło w 1909 r. wraz z oficjalnym uznaniem niepodległości Carstwa Bułgarii.

Znacznie bardziej dotkliwe były ograniczenia nałożone na Bułgarię po klęsce w I wojnie światowej. Na mocy układu podpisanego w Neuilly-sur-Seine 27 listopada 1919 r., państwo bułgarskie poniosło znaczące straty terytorialne i musiało wypłacać sąsiadom wysokie reparacje wojenne. W traktacie narzucono także konieczność

${ }^{1}$ Treaty between Great Britain, Germany, Austria, France, Italy, Russia and Turkey for the Settlement of Affairs in the East, Signed at Berlin, „The American Journal of International Law” 1878, t. 2, nr 4, Supplement: Official Documents (Oct. 1908), s. 401-424.

${ }^{2}$ Ustalono ponadto, że żaden członek dynastii panujących w wielkich mocarstwach europejskich nie będzie mógł być wybrany na księcia Bułgarii; vide Treaty between Great Britain..., art. 2.

${ }^{3}$ M. Dymarski, Ksztaltowanie się systemu politycznego Serbii i Butgarii w XIX i pierwszych latach $X X$ wieku, [w:] Prace Komisji Środkowoeuropejskiej PAU, t. XVIII, red. J. Machnik, I. Stawowy-Kawka, Kraków 2010, s. 35. 
ograniczenia liczebności armii do 20 tys. żołnierzy (art. 66) ${ }^{4}$ oraz obowiązek ochrony mniejszości narodowych (art. 49-57)5. Stworzono także szereg instytucji ograniczających suwerenność Bułgarii. W celu zagwarantowania wypełnienia przez Bułgarię zobowiązań traktatowych powołano Międzysojuszniczą Komisję Kontroli, która w swoich kompetencjach uzyskała prawo sprawowania w dowolnym zakresie kontroli nad działalnością organów państwowych Bułgarii ${ }^{6}$. Ustalenia traktatu z Neuilly zostały uznane przez większość Bułgarów za „klęskę narodową”7.

\section{BULGARSKI PARLAMENT W SYSTEMIE ORGANÓW WLADZY PAŃSTWOWEJ}

Bułgarski parlamentaryzm w okresie od uzyskania częściowej niezależności w 1878 r. do 1946 r. przeszedł dwa wyraźnie odmienne okresy. Pierwszy obejmował złożone procesy tworzenia, rozwoju oraz współdziałania głównych instytucji państwowych w granicach ram prawnych ustanowionych w konstytucji tyrnowskiej. Okres ten był stosunkowo jednorodny i charakteryzował się budową najważniejszych instytucji państwowych i mechanizmów społeczno-politycznych. Zakończył się on wraz z tzw. drugą katastrofą narodową, czyli klęską Bułgarii w I wojnie światowej. Drugi okres charakteryzuje się znacznie bardziej wielowarstwowymi i sprzecznymi procesami politycznymi. Należy w nim wyróżnić dwa podokresy: pierwszy, zakończony przewrotem 19 maja 1934 r., mimo licznych wypaczeń i deformacji zachował cechy rządów konstytucyjnych; drugi, który rozpoczął się od zniszczenia parlamentaryzmu oraz partii politycznych i doprowadził do ustanowienia autorytarnego, bezpartyjnego reżimu kontrolowanego przez monarchę.

Początki życia parlamentarnego w wyzwolonej Bułgarii stanowiło Zgromadzenie Założycielskie ${ }^{8}$. Zostało ono zwołane na podstawie art. 4 traktatu berlińskiego. Obradujący w Tyrnowie od 10 lutego do 16 kwietnia 1879 r. parlament składał się z 229 członków (100 osób wybrano w proporcji jeden na 10 tys. mieszkańców, a pozostali deputowani byli mianowani z urzędu lub reprezentowali stowarzyszenia i organizacje). Zamiast statutu organicznego przewidzianego przez uczestników kongresu berlińskiego, członkowie Zgromadzenia opracowali konstytucję i przyjęli ${ }^{9}$ ją jednogłośnie 16 kwietnia 1879 r. Księstwo Bułgarii zostało określone jako „dziedziczna i konstytucyjna monarchia z przedstawicielstwem narodu"10. Przyjęto zasadę

4 Treaty of Peace Between the Allied and Associated Powers and Bulgaria, and Protocol and Declaration signed at Neuilly-sur-Seine, 27 November 1919.

5 Ibidem.

${ }^{6}$ Annex, Treaty of Peace Between the Allied and Associated Powers and Bulgaria, and Protocol and Declaration signed at Neuilly-sur-Seine, 27 November 1919.

7 Określenie to funkcjonuje również we współczesnej historiografii bułgarskiej.

${ }^{8} \mathrm{~W}$ bułgarskiej literaturze naukowej używane jest również określenie Zgromadzenie Konstytucyjne.

9 Przyjęcie konstytucji nastąpiło nie w wyniku głosowania, lecz przez złożenie podpisów poparcia pod dokumentem.

10 Конституция на Българското Княжество, приета на 16 IV 1879 г. 
trójpodziału władzy. Funkcję prawodawczą miało pełnić jednoizbowe Zgromadzenie Narodowe, które mogło mieć formę zwyczajnego lub wielkiego.

W rzeczywistości formuła niezwykle postępowej i demokratycznej (w owym czasie) konstytucji tworzyła wiele nieporozumień w zakresie wzajemnych relacji między poszczególnymi organami władzy. W konstytucji nie sprecyzowano bowiem jednoznacznie formy rządów. Warto więc przyjrzeć się, jakie uprawnienia posiadały organy władzy państwowej w zakresie władzy ustawodawczej, wykonawczej i sądowniczej.

Głowa państwa - książę (po uzyskaniu pełnej niezależności w 1908 r. car) — został wyposażony w szerokie uprawnienia prawodawcze, jeszcze szerszą władzę wykonawczą oraz niektóre prerogatywy organów sądowniczych. Podobnie jak Zgromadzenie Narodowe posiadał on inicjatywę ustawodawczą (art. 108), a przyjęte przez parlament akty prawne wymagały jego zatwierdzenia (art. 10, art. 45, art. 46). Zdaniem bułgarskich konstytucjonalistów, zatwierdzenie przez władcę było bezwzględnie konieczne dla uzyskania ważności i mocy prawnej każdej ustawy ${ }^{11}$. Głowa państwa zwoływała oraz rozwiązywała Zgromadzenie Narodowe, jak również podejmowała decyzję o przeprowadzeniu wyborów parlamentarnych (art. 137). Jeszcze bardziej rozległe były prerogatywy cara $\mathrm{w}$ odniesieniu do pozostałych organów władzy wykonawczej. Zgodnie $\mathrm{z}$ art. 12 konstytucji „władza wykonawcza należy do księcia, a wszystkie organy tej władzy działają w jego imieniu i pod jego najwyższym nadzorem”. W szczególności mianował on i odwoływał członków rządu (art. 152), którzy za swoje działania odpowiadali przed nim oraz przed Zgromadzeniem Narodowym (art. 153). Władca był zwierzchnikiem sił zbrojnych zarówno w okresie pokoju, jak i w czasie wojny (art. 11). Do cara jako do delegata narodu należało reprezentowanie państwa na zewnątrz oraz zatwierdzanie umów międzynarodowych (art. 17). Partycypowanie władcy we władzy sądowej przejawiało się w mianowaniu sędziów (art. 13), prawie do złagodzenia kar zgodnie z istniejącym porządkiem prawnym (art. 14) oraz prawie ułaskawienia (art. 15). Sam car nie podlegał odpowiedzialności cywilnej i karnej (art. 8).

Pewną próbą ograniczenia władzy cara było wprowadzenie wymogu, aby wszystkie rozporządzenia oraz przepisy przez niego wydane zostały przed ich wejściem w życie podpisane przez odpowiednich ministrów. Dodatkowo zgodnie z art. 47 konstytucji władcy w razie ogłoszenia stanu wyjątkowego przysługiwało prawo wydawania dekretów tymczasowych o mocy ustaw. Za ich wykonanie odpowiadała Rada Ministrów. Ponadto powinny one zostać zatwierdzone przez Zgromadzenie Narodowe.

Sprawująca władzę wykonawczą Rada Ministrów, zgodnie z przepisami konstytucji tyrnowskiej, wykonywała swą władzę ,pod najwyższym nadzorem cara” (art. 12) i ponosiła odpowiedzialność przed władcą oraz przed Zgromadzeniem Narodowym (art. 153). W przypadku naruszenia konstytucji, zdrady lub szkód wyrządzonych państwu dla własnych korzyści ministrowie decyzją podjętą przez Zgromadzenie Narodowe mogli zostać postawieni przed sądem (art. 155). W konstytucji tyrnowskiej przyjęto

11 Vide М.Палангурски, Държсавно-политическата система на България (1879-1919), Велико Търново 1995, s. 17-23; И. Димитров, Князът, конституцията и народът, София 1972, s. 39-50. 
zasadę domniemania kompetencji. Rząd został uprawniony do podejmowania decyzji w sprawach, które nie zostały zastrzeżone dla cara bądź innego organu państwowego. W sytuacji nadzwyczajnej - zewnętrznego lub wewnętrznego zagrożenia dla państwa i wówczas, gdy nie było możliwe zwołanie Zgromadzenie Narodowego — zgodnie $\mathrm{z}$ art. 47 konstytucji nadano Radzie Ministrów prawo do wydania rozporządzeń z mocą ustawy. Kompetencja ta została ograniczona koniecznością zatwierdzenia tego aktu prawnego przez pierwsze zwołane Zgromadzenie Narodowe (art. 47) ${ }^{12}$.

Według przepisów konstytucji tyrnowskiej władzę wykonawczą sprawowało sześć ministerstw ${ }^{13}$. Poprawką do konstytucji z 1911 r. zwiększono liczbę resortów do 10: spraw zagranicznych i wyznań religijnych, spraw wewnętrznych i zdrowia publicznego, oświaty, skarbu, sprawiedliwości, spraw wojskowych, przemysłu oraz handlu i pracy, rolnictwa i majątków państwowych, budowli publicznych i dróg, kolei żelaznych oraz poczty i telegrafów. W konstytucji przyjęto także zasadę szerokich uprawnień dla samorządu terytorialnego, jednak przepisy nie przełożyły się na praktykę.

Zgromadzenie Narodowe, podobnie jak car, posiadało kompetencje w zakresie ustawodawstwa. Według konstytucji istniały dwa rodzaje zgromadzeń narodowych: zwykłe Zgromadzenie Narodowe [dalej: ZN] oraz Wielkie Zgromadzenie Narodowe [dalej: $W Z N]$.

Zgromadzenie Narodowe składało się z posłów wybieranych w wyborach tajnych i powszechnych. Czynne prawo wyborcze posiadali wszyscy mężczyźni, którzy ukończyli 21. rok życia i nie zostali pozbawieni praw politycznych za ciężkie przestępstwa. Bierne prawo wyborcze przysługiwało obywatelom płci męskiej, którzy ukończyli 30. rok życia oraz posiadali umiejętność czytania i pisania (art. 86). Do ZN wybierano posłów na cztery lata w liczbie jednego na 10 tys. wyborców (art. 86). Wybrani posłowie korzystali z prawa nietykalności, które polegało na tym, że nie mogli oni zostać pociągnięci do odpowiedzialności za treść przemówień wygłoszonych w czasie obrad (art. 96) oraz nie mogli zostać aresztowani w okresie zaczynającym się na pięć dni przed rozpoczęciem sesji, a kończącym się wraz z jej upływem (art. 97). Wśród głównych funkcji ZN w art. 105 konstytucji wymieniono: dyskusje nad projektami ustaw i ich przyjmowanie, omawianie i głosowanie budżetu państwa, omawianie i głosowanie propozycji pożyczek państwowych, podatków itp. Bułgarski parlament na mocy art. 44 konstytucji dokonywał także wykładni przyjętych przepisów prawnych.

Poza działalnością prawodawczą ZN za pośrednictwem zapytań i interpelacji sprawowało kontrolę nad działalnością Rady Ministrów (art. 107). Kontrola nad funkcjonowaniem rządu wyrażała się także w odpowiedzialności Rady Ministrów (jako całości) oraz osobistej odpowiedzialności ministrów przez parlamentem. W zakresie odpowiedzialności politycznej ZN mogło wyrażać wotum nieufności Radzie Ministrów i poszczególnym ministrom (art. 153). W przypadku odpowiedzialności karnej

\footnotetext{
12 Na przepisy tego artykułu powoływali się rządzący Bułgarią po przewrocie 19 maja $1934 \mathrm{r}$.

$13 \mathrm{~W}$ art. 161 konstytucji wymieniono kolejno ministerstwa: spraw zagranicznych i wyznań, spraw wewnętrznych, oświaty narodowej, finansów, sprawiedliwości oraz wojny.
} 
parlament, popierając oskarżenie przeciw ministrowi, kierowało sprawę do rozpoznania przez specjalny sąd państwowy (art. 155). Pozycja ZN w systemie władzy państwowej została znacznie ograniczona przez prawo księcia/cara do rozwiązania parlamentu i rozpisania nowych wyborów (art. 136). Ponadto, aby parlament mógł zebrać się na sesję, wymagane było zwołanie go przez władcę (art. 127).

Idea Wielkiego Zgromadzenia Narodowego zawarta została w rozdz. XX konstytucji tyrnowskiej. WZN miało być niezależnym, nadrzędnym organem z następującymi uprawnieniami: odstąpienie lub wymiana części terytorium państwa (art. 141, art. 142); zmiana i przegląd konstytucji (art. 141 p. 2); wybór księcia (kniazia) lub regentów, w sytuacji gdy następca tronu był niepełnoletni (art. 143). W konstytucji tyrnowskiej przewidziano także odmienny poziom reprezentacji niż w odniesieniu do zwyczajnego ZN. W art. 144 zawarto przepis, że liczba deputowanych w WZN miała być dwukrotnie większa niż w zwyczajnym parlamencie.

Wielkie Zgromadzenie Narodowe nie miało ustalonej kadencji. Powoływane było w określonym celu i w momencie wykonania zadania ulegało samorozwiązaniu. Prawo do zwołania WZN posiadał książę, regenci oraz Rada Ministrów. W przypadku gdy obrady ustanawiał władca, decyzje podejmowano większością głosów w odniesieniu do spraw związanych ze zmianami terytorialnymi oraz większością $2 / 3$ wszystkich członków Zgromadzenia w odniesieniu do kwestii związanych ze zmianą lub przeglądem konstytucji (art. 141). Jeśli WZN zostało zwołane przez regentów, mogło rozpatrywać jedynie kwestie związane z terytorium państwa (art. 142). Natomiast Rada Ministrów mogła zwoływać WZN w celu wyboru nowego księcia (decyzję podejmowano większością $2 / 3$ głosów deputowanych obecnych na sali) lub wyboru regentów, w sytuacji gdy następca tronu był niepełnoletni. W tym drugim przypadku decydowano zwykłą większością głosów (art. 143).

W czasie obowiązywania konstytucji tyrnowskiej WZN zwoływano sześciokrotnie. Ostatnie w tym okresie szóste WZN rozpoczęło prace w listopadzie 1946 r. Było to zarazem pierwsze, któremu przydzielono inne zadania niż przewidziane w konstytucji tyrnowskiej.

\section{SPOŁECZNE I POLITYCZNE KONSEKWENCJE I WOJNY ŚWIATOWEJ DLA BULGARII}

Katastrofalny dla Bułgarii wynik I wojny światowej wytworzył w kraju nowe środowisko polityczne, odmienne od przedwojennego. Po pierwsze, car Ferdynand — uznany za głównego winowajcę tej katastrofy — został zmuszony do abdykacji ( 3 października 1918 r.), a na tron wstąpił jego najstarszy syn, który przyjął imię Borys III (4 października 1918 r.). W efekcie Bułgaria była jedynym spośród państw pokonanych, które nie tylko zachowało monarchię jako ustrój, ale pozostawiło na tronie dynastię odpowiedzialną za współpracę z Niemcami i Austro-Węgrami. Co więcej, instytucja monarchy miała odgrywać ważną rolę w życiu politycznym Bułgarii w kolejnych latach. Po drugie, prawicowe partie polityczne zachowały - co prawda jedynie chwilowo - swoją dominującą pozycję w życiu polityczno-społecznym. Po objęciu tronu przez Borysa III 
dotychczasowy premier Aleksandyr Malinow złożył dymisję swojego gabinetu. Rezygnacja nie została jednak przez głowę państwa przyjęta, więc rząd kontynuował swoją działalność, dokonując jedynie niewielkich korekt w swoim składzie ${ }^{14}$. Nowy gabinet nie pracował jednak długo. Protestując przeciwko zajęciu Południowej Dobrudży przez Rumunię, Malinow podał się do dymisji. Na jego miejsce 28 listopada 1918 r. został powołany Teodor Teodorow, jeden z liderów Partii Narodowej. Nowy rząd, będący efektem szerokiej koalicji partii politycznych, stanął przed koniecznością szybkiego rozwiązania przynajmniej dwóch problemów: złagodzenia ogromnego kryzysu gospodarczego, co w konsekwencji miało się przyczynić do ostudzenia nastrojów rewolucyjnych w społeczeństwie, oraz podpisania traktatu pokojowego pozwalającego wyjść Bułgarii z izolacji międzynarodowej ${ }^{15}$. Po wojnie sytuacja gospodarcza kraju była bowiem fatalna. Ze względu na brak surowców, rynków zbytu oraz części zamiennych nie działało ponad $70 \%$ przedsiębiorstw. Większość terenów uprawnych leżała odłogiem. Bezrobocie wśród zdemobilizowanych żołnierzy było ogromne. Dodatkowo sytuację budżetu państwa pogarszała konieczność utrzymywania wojsk okupacyjnych, które jednak pomagały rządowi w tłumieniu wszelkich oznak niezadowolenia wśród ludności ${ }^{16}$.

Klęska Bułgarii w I wojnie światowej doprowadziła do gwałtownej zmiany, wpływając tym samym istotnie na przeobrażenia na bułgarskiej scenie politycznej w okresie powojennym. Na pierwszy plan wysunęły się wówczas właśnie kwestie socjalne i ekonomiczne.

Polityka interwencjonizmu państwowego prowadzona przez kolejne rządy w okresie wojen zyskała wielu zwolenników zarówno w społeczeństwie, jak i w kręgach finansowych. Ich zdaniem pomoc państwa - w okresie powojennym skoncentrowana na jak najszybszej odbudowie gospodarki - powinna stać się trwałym trendem gospodarczym. Podobnie myśleli zwolennicy państwowego kapitalizmu, którzy posiadali znaczące wpływy w bułgarskiej gospodarce. Największe przedsiębiorstwa, jak Bułgarskie Linie Kolejowe (Български държавни железници), kopalnie pernickiego zagłębia węglowego czy fabryki wojskowe były własnością państwa. Idea „uspołecznienia własności środków produkcji” propagowana przez komunistów faktycznie również służyła tym poglądom ${ }^{17}$. Modernizacja bułgarskiej gospodarki doprowadziła do jej bliższego zespolenia w gospodarką europejską, w efekcie narażając Bułgarię na konsekwencje światowego kryzysu gospodarczego z lat 1929-1933 ${ }^{18}$.

Pogłębienie różnic społecznych zmieniło strukturę społeczeństwa, a polaryzacja między poszczególnymi grupami była zauważalna jeszcze przed wojnami. Rosła liczba

${ }^{14}$ W skład Rady Ministrów dołączono po jednym przedstawicielu BZNS oraz BRSDP, jednak nie mieli oni znaczącego wpływu na działanie rządu.

15 Е. Стателова, S. Грънчаров, История на нова България 1879-1944, София 2004, s. 362-365.

16 Е. Калинова, И. Баева, Сочиализмът в огледалото на прехода, София 2011, s. 106-107.

17 Л. Беров, Протекиионизъм на Балканите преди Втората световна война, [w:] Протекиионизъм и конкуренция на Балканите през ХХ век, red. Л. Беров, София 1989, s. 90-95.

18 Р. Аврамов, Стопанският ХХ век на България, София 2001, s. 28-32. 
robotników, którzy stali się bardziej świadomi wspólnoty swoich interesów. Bułgarska klasa średnia, która opanowała sferę gospodarczą, nie wykazywała tendencji do wycofywania się z udziału we władzy politycznej, jednocześnie jednak przestrzegając wyników wyborów. Stanowiąca nadal przytłaczającą większość masa drobnych i średnich przedsiębiorców w kryzysowych momentach zwykle wspierała burżuazję. Ostre podziały wytworzyły znaczną grupę ludzi bezustannie żyjących na granicy minimum socjalnego. Byli oni niezwykle podatni na rozpowszechniane skrajne lewicowe, jak i prawicowe hasła ideologiczne, odrzucające idee parlamentaryzmu na rzecz dyktatury.

Tak jak w momencie odzyskiwania przez Bułgarów swej państwowości w drugiej połowie XIX wieku, również po I wojnie światowej wzrosło znaczenie jednostki w bułgarskiej polityce. Wraz z czołowymi postaciami sfery polityki, działali finansiści i biznesmeni, którzy niechętnie pozbywali się swoich wpływów. Wręcz przeciwnie, ciesząc się znaczną popularnością i wpływając na sferę polityczną, starali się odgrywać coraz większą rolę ${ }^{19}$. Dodatkowo po pewnym odosobnieniu i osłabieniu w pierwszych latach po wojnie, instytucja monarchy odrodziła się i Borys III wzmocnił swoje wpływy. W drugiej połowie lat trzydziestych monarcha zyskał decydującą rolę w systemie politycznym. Stał się główną postacią reżimu bezpartyjnego i autorytarnego, w którym konstytucja tyrnowska oraz parlament stały się fikcją.

Druga katastrofa narodowa odroczyła realizację bułgarskich ideałów zjednoczenia narodowego na czas nieokreślony. Porażka wojenna stała się katalizatorem wielu sprzeczności wewnątrz kraju. Marzenia okresu przedwojennego pozostały niespełnione, na poważną próbę zostało wystawione poczucie wspólnoty narodowej. Zdaniem bułgarskiego historyka Nikołaja Genczewa, w wyniku drugiej katastrofy narodowej oraz pod wpływem międzynarodowej izolacji kraju wśród Bułgarów zrodził się złożony kompleks narodowo-psychologiczny, który niektórym Bułgarom umożliwił przejście do nihilizmu narodowego, a innym do bolesnego nacjonalizmu ${ }^{20}$. Katastrofa narodowa objęła nowe środowiska (przeważnie intelektualne i wojskowe), które do tej pory nie były zaangażowane w walki polityczne i doprowadziła do skrajnego upolitycznienia ruchu wyzwolenia narodowego, którego działalność jako „czynnika nieponoszącego odpowiedzialności za katastrofę" odegrała wyjątkowo negatywną rolę w walkach politycznych wewnątrz kraju w omawianym okresie ${ }^{21}$.

Miejsce oraz rola czynników zewnętrznych na sytuację wewnętrzną Bułgarii zostały ustalone w traktacie pokojowym z Neuilly-sur-Seine. Niepomyślny bilans po zakończeniu I wojnie światowej sprowadzał się nie tylko do poważnego okrojenia terytorialnego i pogłębienia trudności gospodarczych, ale także do szeregu ograniczeń naturalnego rozwoju kraju. Do 1927 r. zwycięskie mocarstwa utrzymywały możliwość interwencji w Bułgarii za pośrednictwem Międzysojuszniczej Komisji Kontroli.

19 Е. Стателова, S. Грънчаров, op. cit., s. 364-365.

20 Н. Генчев, Очеричи. Сочииално-психологически типове в българската история, София 2011, s. $14-15,205-208$.

${ }^{21}$ К. Палешутски, Македонското освободително движение след Първата световна война 1918-1924, София 1993, s. 46-58. 
Dotkliwe konsekwencje od samego początku były kontestowane przez władze oraz społeczeństwo bułgarskie, co prowadziło do międzynarodowej izolacji oraz złych relacji $\mathrm{z}$ sąsiadami ${ }^{22}$. W dłuższej perspektywie na trwałe związały bułgarskich polityków z mocarstwami dążącymi do rewizji systemu wersalskiego. Realizacja podstawowego celu bułgarskiej polityki zagranicznej — rewizji traktatu z Neuilly i odzyskania utraconych terytoriów — była bowiem możliwa dzięki wsparciu III Rzeszy i Włoch ${ }^{23}$.

5. KRYZYS POWOJENNY (1918-1923)

Klęska militarna oraz tzw. druga katastrofa narodowa wywołały ostry kryzys polityczny oraz znacząco wpłynęły na układ sił na bułgarskiej scenie politycznej. Rządzące dotychczas partie burżuazyjne zostały zdyskredytowane, co w połączeniu z nastrojami rewolucyjnymi wśród mas spowodowało wyraźne przesunięcie sympatii politycznych na lewo. Na pierwszy plan, ze względu na działalność antywojenną oraz radykalne programy reformatorskie, wysunęły się Bułgarska Robotnicza Partia Socjaldemokratyczna (Българската работническа социалдемократическа партия, dalej: BRSDP) oraz właśnie Bułgarski Związek Narodowo-Chłopski (Български земеделски народен съюз, dalej: BZNS).

Przyjęcie zasad bolszewizmu przez tzw. wąskich socjalistów BRSDP (w maju 1919 r.), dołączenie do Kominternu i przemianowanie nazwy partii na Bułgarska Partia Komunistyczna „wąscy socjaliści” (Българската комунистическа партия „тесни социалисти", dalej: BKP t.s.) stopniowo przekształciło to ugrupowanie w propagatora sowieckiego modelu politycznego i przeciwnika demokracji parlamentarnej. Część działaczy tej partii, tzw. lewi komuniści, całkowicie odrzuciła uczestnictwo w wyborach parlamentarnych, wzywając do masowych zbrojnych działań mających doprowadzić do przejęcia władzy i ustanowienia dyktatury proletariackiej. Pod wpływem BKP t.s. część czołowych działaczy BRSDP na czele w Georgim Bakałowem i Nikołą Sakarowem odrzuciła idee socjaldemokratyczne i w maju 1920 r. weszła do BKP t.s. Partie BZNS oraz BRSDP realizowały idee parlamentaryzmu, zwiększając swój udział w kolejnych gabinetach rządowych. Usiłowały też wprowadzać radykalne reformy społeczne: pierwsze z ugrupowań chciało poprawić sytuację chłopów, a drugie - robotników.

Tradycyjne parlamentarne partie polityczne otrzymały potężny cios. Obie partie liberalne stanowiące zaplecze dla rządu Wasila Radosławowa pozbawiono władzy. Uznane za winne „katastrofy narodowej” zostały izolowane na scenie politycznej i utraciły poparcie wśród wyborców. Pozbawione wpływów oraz przywódców ${ }^{24}$ stanęły przed groźbą całkowitego zniknięcia ze sceny politycznej. Znacznego osłabienia

${ }^{22}$ Szerzej na temat sytuacji międzynarodowej Bułgarii vide E. Znamierowska-Rakk, Bułgarski rewizjonizm terytorialny a zblizenie z III Rzeszq, „Studia z Dziejów Rosji i Europy Środkowo-Wschodniej” 2009 , t. XLIV, s. $77-100$.

${ }^{23}$ Ibidem, s. 79.

${ }^{24}$ Pod naciskiem opinii społecznej ZN 22 listopada 1919 r. uchwaliło ustawę o ukaraniu winnych wciągnięcia Bułgarii do I wojny światowej. W jej wyniku pod sąd trafili ministrowie rządu Radosławowa oraz politycy popierający ich w czasie wojny. 
doznały także dotychczasowe partie parlamentarne: Narodowa (Народна партия, dalej: NP), Demokratyczna (Демократическа партия, dalej: DP), Radykalno-demokratyczna (Радикалдемократическа партия, dalej: RDP) oraz Postępowo-liberalna (Прогресивнолиберална партия, dalej: PLP). Poszukując wyjścia z kryzysu politycznego, jeszcze w 1918 r. partie te zaprosiły do współtworzenia rządu zarówno BZNS, jak i BRSDP. Głównym celem miało być uspokojenie sytuacji wewnątrz kraju, mające służyć podpisaniu korzystnego układu pokojowego. Dodatkowo liderzy partii demokratycznych (DP i RDP) nawoływali do „zjednoczenia pokrewnych sił politycznych” $\mathrm{w}$ celu przeciwstawienia się rosnącym wpływom radykalnej lewicy. W konsensie zawartym między umiarkowanymi ugrupowaniami (BZNS, NP, DP, RDP, PLP oraz tzw. szerokimi socjalistami BRSDP) przewidziano wprowadzenie pakietu reform gospodarczych, nie zdecydowano się jednak na reformę systemu parlamentarnego i instytucji monarchii jako gwarantujących utrzymanie porządku prawnego w kraju ${ }^{25}$.

Przeprowadzone w sierpniu $1919 \mathrm{r}$. wybory parlamentarne potwierdziły marginalizację tradycyjnych partii politycznych i znaczący wzrost wpływów BZNS oraz BKP t.s. Dnia 19 września 1919 r. Stambolijski otrzymał od cara Borysa III mandat do utworzenia nowego rządu. Ludowcy nie posiadali jednak wystarczającej liczby deputowanych i zmuszeni byli do tworzenia rządu koalicyjnego, w którego skład weszli także przedstawiciele NP i PNP. Podpisanie traktatu w Neuilly-sur-Seine oraz rozprawienie się ze strajkiem generalnym w grudniu 1919 r. wzmocniły pozycję szefa ludowców, wobec czego zwrócił się on do cara z prośbą o rozpisanie nowych wyborów. Borys III przychylił się do tej propozycji i wyznaczył nowe wybory na 28 marca 1920. Tym razem sukces BZNS był ogromny, więc Stambolijski nie zdecydował się na koalicję. Zamiast tego przeforsował pomysł, aby pod pozorem naruszenia ordynacji wyborczej unieważnić mandaty 13 deputowanym. To pozwoliło BZNS na uzyskanie większości w parlamencie i stworzenie samodzielnego rządu.

\section{RZĄDY PARTII CHLOPSKIEJ}

Utworzenie samodzielnego gabinetu rządowego przez autentycznie chłopską partię, jaką był BZNC, było zjawiskiem specyficznym dla Bułgarii i wyjątkowym w całej Europie. Dojście partii ludowej do władzy było możliwe w sytuacji, gdy stare elity polityczne utraciły autorytet i zaufanie społeczne w wyniku uwikłania państwa w udział w przegranych wojnach bałkańskich i I wojnie światowej, a idee głoszone przez przedstawicieli Bułgarskiej Partii Komunistycznej były zbyt radykalne i budziły obawy umiarkowanej części społeczeństwa. Rządy partii chłopskiej przypadły jednak na trudny okres, powojenny kryzys nadal bowiem dawał się we znaki całemu społeczeństwu. Priorytetem rządu Stambolijskiego było więc poprawienie sytuacji gospodarczej kraju, w związku z czym na początku zainicjował on wiele reform ekonomicznych i społecznych.

${ }^{25}$ W zamian za utrzymanie ,starego porządku” BZNS domagał się poparcia ustawy o amnestii politycznej. Przegłosowany przez ZN akt prawny pozwolił powrócić do czynnej polityki liderom ludowców: A. Stambolijskiemu (wypuszczonemu z więzienia) oraz R. Daskałowowi (który wrócił z emigracji). 
Reformatorskie ambicje przywódcy ludowców szybko zostały przekute na realne działania. Praktycznie nie było żadnej sfery życia, w której rząd BZNS nie podjął z wielkim rozmachem reform legislacyjnych i administracyjnych, łącząc je ze zdecydowaną retoryką socjalną (sprawiedliwość, władza ludu, pracowitość itp.). Najważniejsze i najbardziej trwałe okazały się: reforma rolna, państwowe wsparcie i promocja ruchu spółdzielczego, reforma edukacji, wprowadzenie przymusu pracy publicznej ${ }^{26}$. W rzeczywistości jednak wiele głośnych zmian, które miały być rewolucyjne, miało ograniczony zasięg. Reforma rolna, będąca priorytetem rządu Stambolijskiego, w niewielkim stopniu dotknęła ziem prywatnych i kościelnych, ponieważ w Bułgarii dominowały drobne gospodarstwa, a utworzony fundusz powstał głównie kosztem ziemi państwowej i gminnej ${ }^{27}$. Próby wprowadzenia monopolu producentów na handel płodami rolnymi spotkały się ze sprzeciwem Komisji Międzysojuszniczej. Wprowadzony progresywny podatek w praktyce okazał się nieściągalny. Mianowanie nauczycieli szkół podstawowych w lokalnych referendach okazało się niepraktyczne.

Jednocześnie epatując swoją wiejskością, rewolucyjną arogancją, usuwaniem tradycyjnych elit oraz stosowaną retoryką antyburżuazyjną, antymiejską i antyintelektualną, rząd ludowców wzbudzał wrogość wielu środowisk. Partie burżuazyjne, których istnienie ludowy kwestionowali, wyrażały swoje niezadowolenie. Oficerowie mocno odczuli demobilizację i ciągłe zniewagi ze strony premiera. Stambolijski słownie atakował także działaczy macedońskich, prawników, przedstawicieli kręgów naukowych oraz wyższych urzędników ${ }^{28}$. Jednocześnie BZNS popadł w ostry konflikt z komunistami, zdecydowanie rozbijając wielki strajk transportowy w 1919 r. Jak relacjonował słowa Stambolijskiego jeden z jego bliskich współpracowników: „Nie zdziw się, jeśli Ci powiem, że nasze rządzenie nie jest rządzeniem, a wielką wojną. Prawdziwą wojną wewnętrzną i zewnętrzną. Wojną z kolejarzami, wojną ze zbójami z lasów, wojną z przestępcami w miastach, wojną w nauczycielami, wojną z partiami, wojną z Ligą Wojenną, wojną $\mathrm{z}$ nienawiścią i nieufnością do nas, wojną z urzędnikami, wojną z błogosławionym świętym synodem"29.

Środowiska burżuazyjne i inteligenckie uważały rząd BZNS za zacofany, dyletancki, niekompetentny, prowadzący do „zerwania” bułgarskiej wsi z cywilizacją. W swoich zamierzeniach Stambolijski starał się zapewnić rozwój i ożywienie gospodarcze na wsi, bez walki z rozwojem przemysłowym. Swoje działania kierował jednak przeciwko własności prywatnej i niezależnym przedsiębiorcom. Należy więc zgodzić się z tezą Richarda Cramptona, że rząd Stambolijskiego prezentował postawę „niechętnych modernizatorów”, mających „statyczną i irracjonalną wizję społeczeństwa,

${ }^{26}$ Zgodnie z ustawą z 14 czerwca 1920 r., każdy mężczyzna po ukończeniu 20. roku życia miał obowiązek wykonywania prac publicznych. Obowiązek taki miały także kobiety po 16. roku życia. W tym drugim przypadku przymusowe prace wykonywały przez sześć miesięcy; vide законът за трудовата повинност, ДВ, бр. 56 от 14 юни 1920 г.

27 А. Велев, Главни реформи на земеделското правителство, София 1977, s. 40-42.

28 М. Геновски, Александър Стамболийски - отблизо и отдалеко, София 1982, s. 144-147, $218-219$.

${ }^{29}$ К. Кацаров, Шесдесет години живяна история, София 1970, s. 312-313. 
reformując kraj na podstawie egalitarnej teorii agraryzmu, opierając się na grubiaństwie i demagogii" ${ }^{30}$.

Rządzący z BZNS, opowiadający frazesy o ,rządach ludu”, bardzo często przekraczali granice praworządności, np. anulując mandaty deputowanych opozycji, arbitralnie zwalniając i nominując urzędników, przyjmując niezgodne z konstytucją akty prawne. Sam aparat państwowy również był wielokrotnie pomijany przy realizacji reform ludowców. Zemedelcy nie liczyli się także z opozycją, zarówno z burżuazyjną (wyroki dla winnych katastrof narodowych, które zapadły 17 września 1922 r.), jak i komunistyczną. Przyczyn takiego zachowania można upatrywać nie tylko w arogancji Stambolijskiego, ale przede wszystkim w rewolucyjnych intencjach BZNS. Nie należy zapominać o nadzwyczajnym charakterze powojennej sytuacji w Bułgarii, a także o nieprzygotowaniu ludowców do sprawowania rządów, będącego przede wszystkim efektem braku doświadczenia kadr. Jednocześnie wielu członków BZNS wykorzystywało przynależność do partii dla własnych korzyści. Nie bacząc na posiadane kompetencje i umiejętności, na odpowiedzialne stanowiska mianowano „własnych ludzi”. Przywódca BZNS uważał bowiem, że to chłopi powinni obejmować ważne stanowiska w państwie ${ }^{31}$. Pozwalało to łatwiej korumpować władze przez (tak krytykowane przez Stambolijskiego) koterie burżuazyjne, co zraziło nawet bardziej umiarkowane środowisko wiejskie.

Dimitrina Petrowa w monografii poświęconej rządom BZNS zauważa, że w trakcie sprawowania władzy Stambolijski upośledził bułgarską demokrację, próbując ją zamienić w dyktaturę wsi ${ }^{32}$. Premier podejmował działania niezgodne z art. 57 konstytucji, którym zabraniano tworzenia systemu władzy państwowej na podstawie podziałów klasowych. Liczne przejawy antydemokratycznych i antyparlamentarnych działań z czasem prowadziły do zaostrzenia konfrontacji politycznej. Przeprowadzono swoistą bolszewizację BZNS, szczególnie pod wpływem tajnego, skrajnie lewicowego Komitetu Dyktatury Wiejskiej, utworzonego pod koniec 1921 r. i cieszącego się ogromną sympatią Stambolijskiego. Jednym z głównych zadań Komitetu było utworzenie i organizacja tzw. pomarańczowej gwardii. Jej jednostki miały stanowić jeden $\mathrm{z}$ istotnych elementów dyktatury Stambolijskiego. Podlegające bezpośrednio szefowi partii miały stanowić alternatywę militarną dla zdemobilizowanych oficerów armii bułgarskiej, a także dla byłych żołnierzy gen. Wrangla, którzy znaleźli schronienie w Bułgarii po ucieczce z Rosji. W praktyce przy pomocy pomarańczowej gwardii Stambolijski rozpoczął masowe represje wobec członków Bułgarskiej Partii Komunistycznej, a także przeciwko partiom burżuazyjnym.

Stambolijski, dążąc do wzmocnienia swej władzy, polecił Komitetowi Dyktatury Wiejskiej opracowanie projektu nowej konstytucji ${ }^{33}$. W okresie swoich rządów BZNS tworzył warunki dla ustanowienia jednoosobowej dyktatury oraz wykazywał

${ }^{30}$ R. Crampton, Modernization: Conscious, Unconscious and Irrational, [w:] Industrialisierung und gesselschaftlicher Wandel in Südosteuropa, red. R. Schoenfeld, München 1989, s. 127-129.

${ }^{31}$ А. Велев, op. cit., s. 130.

32 Д. Петрова, Българският земеделски народен съюз, 1899-1944, София 1999, s. 95.

33 Według przygotowanego projektu ograniczeniu miała ulec przede wszystkim władza cara, który miał pełnić funkcję reprezentatywną. 
tendencje do scalania swojej partii oraz instytucji państwowych. Dążeniom tym towarzyszyło ograniczanie roli parlamentu. Stambolijski nie ukrywał zresztą, że jest przeciwnikiem systemu wielopartyjnego. Jego zdaniem partie polityczne były jedynie sitwami kierowanymi przez ambitnych polityków, służącymi wyłącznie zdobyciu władzy ${ }^{34}$. Przywódca ludowców nie zdecydował się na oficjalne zniesienie systemu partyjno-politycznego, lecz w czasie jego rządów stracił on na znaczeniu. Podobnie została ograniczona rola ZN. Natychmiast po wyborach anulowano - pod różnymi pretekstami - 13 mandatów posłów opozycji. Spowodowało to zmniejszenie liczby deputowanych i osiągnięcie przez BZNS większości w parlamencie. Dysponując odpowiednią większością, Stambolijski wykorzystywał parlament jako „maszynkę do głosowania" akceptującą kolejne projekty rządowe. W dużej mierze właśnie dlatego, że ZN nie stanowiło przeszkody w realizacji celów, Stambolijski nie odrzucił całkowicie demokracji parlamentarnej, ale działał w jej ramach i utrzymywał przywiązanie do niej. Ostatecznie to dzięki zachowaniu wielopartyjności i nieprzerwanemu funkcjonowaniu parlamentu możliwy stał się spisek przeciwko władzy, a następnie zamach stanu, w którym obalono Stambolijskiego.

Należy podkreślić, że reżim ludowców skutecznie zmarginalizował pozycję monarchy. Mimo swoich republikańskich poglądów Stambolijski nie zdecydował się wystąpić otwarcie przeciwko carowi. W praktyce jednak zarzucono konstytucyjną zasadę odpowiedzialności rządu przed monarchą, a młody i niedoświadczony car Borys III nie był w stanie w tym okresie odegrać żadnej roli politycznej. Brak czynnika balansującego władzę wykonawczą rządu prowadził do dyktatury partyjnej. Oczywiście należy pamiętać o masowości i silnym rewolucyjnym charakterze partii chłopskiej prowadzonej przez charyzmatycznego przywódcę.

\section{KONSOLIDACJA OPOZYCJI I UPADEK RZĄDÓW LUDOWCÓW}

Poczynając od 1919 r., pojawiły się nowe siły polityczne, odrzucające nie tylko obowiązujące mechanizmy parlamentaryzmu, ale także demokrację parlamentarną w ogóle. To w niej widziano główną przyczynę katastrof narodowych. Ideom liberalizmu i demokracji przeciwstawiano skrajny nacjonalizm, dążenie do „silnej władzy” oraz interwencjonizm państwowy, zarówno w kwestiach gospodarczych, jak i społecznych. Poglądy te były szczególnie popularne w kręgach wojskowych oraz wśród inteligencji. Przeciwstawiano „rządy kompetentnych” i „kreatywność elit” „niekompetentym rządom” $\mathrm{i}$ „,niszczycielskiej sile mas”35. Wokół tych idei powstała grupa organizacji skłaniająca się ku autorytaryzmowi i dyktaturze. Ich głównymi celami było zachowanie pokoju społecznego i stabilizacja państwa, które uważano za „dobro publiczne” i jedyne narzędzie realizacji narodowego zjednoczenia. Poglądy propagowane przez utworzony w $1919 \mathrm{r}$. Związek Wojskowy (Военният съюз) ${ }^{36}$, zyskiwały na popularności i następnie były roz-

34 М. Геновски, op. cit., s. 160-162.

35 А. Цанков, България в бурно време. Спомени, София 1998, s. 17-23, 107-130.

36 Bułgarska organizacja wojskowa powstała w 1919 r. Jej celem było reprezentowanie interesów kadry oficerskiej (w tym również oficerów rezerwy). 
wijane przez ugrupowania burżuazyjne, które dążyły do odzyskania utraconych wpływów. Realizacja głoszonych postulatów miała opierać się nie na poparciu szerokich mas społecznych, lecz na interwencji armii w życie polityczne kraju. Idee wojskowego zamachu stanu propagował Aleksander Cankow, lider Porozumienia Narodowego (Народен сговор), który latem 1922 r. zjednoczył opozycję pozaparlamentarną i parlamentarną tworząc tzw. blok konstytucyjny. Zjednoczenie opozycji zostało wymuszone działaniami rządu Stambolijskiego. 19 listopada 1922 r. rząd przeprowadził referendum w sprawie osądzenia polityków odpowiedzialnych za klęski Bułgarii w 1913 i 1918 r. ${ }^{37}$ Wyeliminowanie z życia politycznego wielu prominentnych i aktywnych polityków prawicy w znaczący sposób osłabiło opozycję.

Elementem utrwalającym dominującą pozycję BZNS na bułgarskiej scenie politycznej były wybory przeprowadzone wiosną $1923 \mathrm{r}$. Stambolijski zdawał sobie sprawę ze znaczenia wyniku wyborczego, postanowił się więc do elekcji odpowiednio przygotowa. Przeprowadzono wówczas rekonstrukcję rządu, wzmocniono propagandę antykomunistyczną, przygotowano i przeprowadzono zmianę ordynacji wyborczej. Kiedy ludowcy w wyborach zdominowali $\mathrm{ZN}^{38}$, partie opozycji czyniły już przygotowania do siłowego przejęcia władzy. Gdy spisek przeciwko rządowi poparł car Borys III, zdecydowano o dokonaniu przewrotu. Zamach stanu przeprowadzono w nocy z 8 na 9 czerwca 1923 r., obalając rząd Stambolijskiego. Sam premier został aresztowany niedaleko swej rodzinnej wsi, następnie poddany torturom zmarł 14 czerwca $1923 \mathrm{r}$.

\section{POD ZNAKIEM AUTORYTARYZMU PRAWICOWEGO}

W wyniku wojskowego zamachu stanu z 9 czerwca 1923 r. władzę w kraju przejęło Porozumienie Narodowe, wspierane przez Związek Wojskowy. Na czele nowego rządu stanął A. Cankow, który jednak w początkowym okresie rządów pozostawał pod ogromnym wpływem nieformalnej grupy wojskowych skupionych wokół ministra obrony gen. Iwana Wyłkowa. Reżim przy użyciu jednostek wojskowych podległych Lidze Wojskowej, a także czetników z WMRO brutalnie tłumił lewicowy ruch oporu. Podstawą do działań przeciwko opozycji była uchwalona 1 kwietnia 1924 r. ustawa o obronie państwa, którą zakazywano działalności organizacjom uciekającym się do

37 Przygotowaną przez BZNS i przyjętą przez parlament 9 grudnia 1919 r. ustawą o sądzeniu i ukaraniu winnych katastrofy narodowej powołano specjalny (ad hoc) trybunał do konkretnych działań i w celu ukarania konkretnych osób. Był on odpowiedzią na poszukiwanie sprawiedliwości i odpłaty za cierpienia wojenne i powojenne. Warto jednak zaznaczyć, że było to niezgodne z konstytucją, a także z podstawowymi zasadami prawa, ponieważ było to działanie z mocą wsteczną. Proces przeciwko członkom rządu Radosławowa rozpoczął się w 1920 r., a wyroki wydano 31 marca 1923 r. Natomiast postępowanie sądowe wobec członków gabinetu Malinowa-Kosturkowa rozpoczęto po pozytywnym wyniku referendum w 1922 r. Wpływ na dalsze losy oskarżonych w obu sprawach miał przewrót lipcowy w 1923 r. W jego efekcie przerwano proces wobec gabinetu Malinowa-Kosturkowa, a skazanych członków rządu Radosławowa objęła amnestia ogłoszona 21 czerwca 1924 r., będąca efektem zmiany władzy w wyniku przewrotu z 1923 r.; vide Т. Галунов, Третият държавен съд (1921-1923), „Исторически преглед", 1996, nr 5, s. 47-65.

38 BZNS wprowadził do 245-osobowego Zgromadzenia Narodowego 212 przedstawicieli. 
przemocy. Na podstawie tej ustawy zdelegalizowano BKP, pozbawiono mandatów komunistycznych deputowanych oraz zdelegalizowano związki zawodowe. W kwietniu 1925 r. rząd Cankowa wprowadził na sześć miesięcy stan wojenny z sądami polowymi ${ }^{39}$, co pozwoliło na prawne usankcjonowanie rządowego terroru ${ }^{40}$. Terror prowadził jedynie do eskalacji przemocy i coraz większej liczby ofiar po obu stronach. Ostatecznie wobec obaw związanych z niebezpieczeństwem likwidacji parlamentarnej formy rządów car Borys III zdecydował o zdymisjonowaniu Cankowa na początku stycznia $1926 \mathrm{r}^{41}$

Charakterystyczna dla ideologii Porozumienia Narodowego była postawa ponadpartyjności. W swych działaniach jego zwolennicy dążyli do przezwyciężenia rozdrobnienia partii burżuazyjnych poprzez ich reorganizację i konsolidację. Sformowanie jednolitej, prawicowej siły politycznej miało być krokiem pozwalającym na gruntowną reformę instytucji publicznych, której celem miało być wzmocnienie roli państwa. Ideałem było państwo monopartyjne, którego podstawę miała stanowić posiadająca szerokie uprawnienia administracja państwowa. Jednak idea silnej władzy państwa w połączeniu z realizowanym interwencjonizmem gospodarczym wywoływały niezadowolenie nawet w niektórych kręgach biznesowych. Zdaniem Cankowa miały one jednak służyć — w połączeniu z reformą społeczną — łagodzeniu konfliktu społecznego w sytuacji zagrożenia destabilizacją polityczną ${ }^{42}$.

Wraz z utworzeniem drugiego rządu Porozumienia Narodowego, na czele którego stanął Andrej Ljapczew, centrum ciężkości przeniesione zostało z kręgów wojskowych do partyjnych sfer Porozumienia Narodowego (ludzie związani z Ljapczewem i Atanasem Burowem). Oznaczało to także zakończenie brutalnych represji i pacyfikacji działaczy lewicowych. Autorytaryzm został osłabiony, a nowy premier przestał łamać obowiązującą konstytucję. Działalność komunistów i ludowców została zalegalizowana z nadzieją, że kiedy będą działać legalnie, przyjmą kurs pokojowy. Nowy rząd zasadniczo zmieniał także politykę gospodarczą. Ograniczono ingerencję państwa w gospodarkę, z czasem zaprzestano faworyzowania spółdzielni. Wszelka ingerencja państwa po 1930 r. była wymuszana przez sytuację gospodarczą.

W 1931 r. po wolnych wyborach (jednych z nielicznych w okresie międzywojennym) do władzy doszedł Blok Narodowy — koalicja zbudowana wokół Partii Demokratycznej oraz BZNS. Zamiast wyraźnego przełomu w ,nieistniejącej dyktaturze faszystowskiej”’3 , w polityce Bloku Narodowego można było jednak dostrzec wyraźną kontynuację polityki drugiego gabinetu Porozumienia Narodowego. Podtrzymano

39 Wprowadzenie stanu wojennego było konsekwencją zamachu bombowego dokonanego 16 kwietnia 1925 r. w cerkwi „Święta Niedziela”, w którym zginęło wielu członków rządu oraz oficerów Związku Wojskowego.

${ }^{40} \mathrm{H}$. Недев, Прекъснатост или непрекъснатост на фашистката диктатура в България (1923-1944), „Исторически преглед” 1989, nr 8, s. 78.

${ }^{41}$ M. Tanty, Batkany w XX wieku. Dzieje polityczne, Warszawa 2003, s. 167-168.

42 Р. Гришина, Возникновение фашизма 1919-1925, София 1976, s. 140-148, 186-189.

${ }^{43}$ Określenie użyte po raz pierwszy przez G. Dimitrowa, obecnie używane w bułgarskiej historiografii; vide П. Цветков, Н. Поппетров, Към типологията на политическото развитие на България през 30-те години, „Исторически преглед” 1990, nr 2, s. 66. 
wówczas działania zmierzające do łagodzenia konfliktów społecznych oraz demokratyzacji życia politycznego. Dlatego nawet osłabienie liberalizmu gospodarczego i ponowne zwiększenie roli państwa w sferze ekonomicznej nie prowadziło do odwrotu od demokracji parlamentarnej. Stworzony przez Blok Narodowy rząd napotykał jednak wiele problemów wewnętrznych. Wewnątrz koalicji dochodziło do częstych sporów dotyczących obsady stanowisk. Upartyjnienie administracji państwowej, tworzenie dobrze płatnych stanowisk i obsadzanie ich własnymi ludźmi nieposiadającymi kompetencji w połączeniu z powszechną korupcją powodowały, że rząd bardzo szybko został zdyskredytowany w oczach społeczeństwa. Działalność kolejnych rządów Bloku Narodowego była skoncentrowana na próbie przezwyciężenia załamania koniunktury gospodarczej, będącej efektem światowego kryzysu ekonomicznego. Brak sukcesów, a także konflikty wewnątrz koalicji związane z obsadzaniem ważnych stanowisk stały się przyczyną dekompozycji obozu rządowego ${ }^{44}$. I ta słaba, rozpadająca się koalicja stanowiła podstawę dla utworzenia „bezideowych, nieudolnych i małostkowych rządów”45, które straciły energię i zaufanie do siebie ${ }^{46}$. Rozczarowanie rządami Bloku Narodowego przyczyniło się także do powszechnej krytyki demokracji, a także agresji wobec partii politycznych. Jednocześnie społeczeństwo coraz wyraźniej domagało się silnej władzy i twardych rządów. Argumentowano, że reżimy autorytarne zbudowane w innych krajach środkowoeuropejskich okazały się skutecznymi rozwiązaniami ${ }^{47}$.

Zamach stanu w dniu 19 maja 1934 r. został przeprowadzony przez spiskowców z Klubu Politycznego Zweno oraz Związku Wojskowego. W skład nowego rządu, na czele którego stanął Kimon Georgiew, weszli niemal wszyscy najważniejsi działacze obu przeprowadzających zamach organizacji ${ }^{48}$. Rząd rozwiązał ZN i zakazał działalności partii i organizacji politycznych ${ }^{49}$. Zniesiono konstytucyjne prawa i wolności (słowa, zgromadzeń i inne) oraz wprowadzono cenzurę. W ten sposób konstytucja bez jej formalnego uchylenia - przestała być respektowana. Władze wydawały dekrety z mocą ustawy, bezprawnie powołując się na art. 47 konstytucji ${ }^{50}$.

\section{PODSUMOWANIE}

Parlamentaryzm w Bułgarii w okresie międzywojennym był bardzo niestabilny i zdeformowany na różne sposoby. W szczególności przejęcie władzy w wyniku przewrotów (rok 1923 i 1934), działania antykonstytucyjne, łamanie praw i swobód obywatelskich czy wszechobecną przemoc polityczną. W całym dwudziestoleciu demokracja parlamentarna była poddawana ciągłym atakom z prawej i z lewej strony

${ }^{44}$ M. Tanty, op. cit., s. 169-170.

${ }^{45}$ К. Кацаров, op. cit., s. 449.

46 Д. Казасов, Видяно и преживяно 1891-1944, София 1969, s. 464-466.

47 S. Попов, Безсъници, София 1992, s. 32-50; Д. Казасов, op. cit., s. 448-453.

${ }^{48}$ Wyjątkiem był D. Wełczew, sekretarz Związku Wojskowego i faktyczny jego przywódca, który nie przyjął oficjalnego stanowiska.

${ }^{49}$ Formalnie zostało rozwiązane również KP Zweno.

${ }^{50}$ Zgodnie z art. 47 konstytucji tyrnowskiej, rząd miał uprawnienia do wydawania dekretów w stanie nagłego zagrożenia wewnętrznego lub zewnętrznego. 
sceny politycznej. Mimo to w osłabionej i okrojonej formie zdołała się ona utrzymać w Bułgarii do 1934 r. W każdym razie mimo rządów autorytarnych zachowano elementy demokracji np. ograniczoną działalność partyjną, pozwalającą na funkcjonowanie opozycji parlamentarnej; pluralizm idei politycznych; względnie niezależny system sądowniczy i przynajmniej w formie deklaracyjnej przestrzeganie przepisów konstytucji. Te czynniki przez wiele lat nie pozwalały na całkowity upadek elementów demokracji i ostateczną zmianę miękkiego autorytaryzmu w totalitarną kontrolę władzy nad wszystkimi sferami życia publicznego ${ }^{51}$. Zdaniem Kristo Manczewa, ,nawet jeśli ten pluralizm wynikał ze słabości władzy, a nie z jej intencji, to nadal istniał" ${ }^{52}$. Z formalnego punktu widzenia w okresie do maja 1934 r. jedynie zamach stanu z 9 czerwca $1923 \mathrm{r}$. był aktem antykonstytucyjnym.

Należy jednak podkreślić, że istnieje znacząca różnica między parlamentaryzmem podczas rządów Bułgarskiego Związku Narodowo-Chłopskiego a rządami prawicowymi do 1934 r. Dzięki ambicjom Stambolijskiego do 9 czerwca 1923 r. bułgarski parlamentaryzm został zniekształcony poprzez narzucenie ,wiejskiej” demokracji. Funkcjonował on w warunkach supremacji jednej partii politycznej, która podjęła się zadania obrony interesów ludności wiejskiej. W efekcie dobro tej grupy społecznej utożsamiano z interesem państwa. Z kolei rząd Cankowa przedstawiano jako „ponadklasowy” i ,ponadpartyjny", jednak interes państwa, który miał być celem nadrzędnym, stanowił jedynie fasadę. I chociaż reżim nie negował istniejącego porządku prawnego opartego na konstytucji tyrnowskiej i systemie parlamentarnym, to nie dążył w ramach tego systemu do demokracji, ale do dyktatury, co przejawiało się również w zorganizowanych represjach wobec przeciwników politycznych.

Demokracja parlamentarna w Bułgarii w okresie miedzywojennym najpierw była zdeformowana poprzez naruszanie zasad funkcjonowania parlamentu i podporządkowanie go interesom partyjnym, a następnie osłabiana poprzez uzurpację władzy (dwa zamachy stanu), braku poszanowania wobec przepisów konstytucji oraz poprzez przepisy zakazujące aktywności niektórych sił politycznych. W efekcie Bułgaria w omawianym okresie przeszła drogę od monarchii parlamentarnej, respektującej system parlamentarny oraz procedury, do dyktatury.

\section{BIBLIOGRAFIA}

ŹRÓDŁA

Konstitucija na Byłgarskoto Knjażestwo z 16 kwietnia 1879 r.

Treaty between Great Britain, Germany, Austria, France, Italy, Russia and Turkey for the Settlement of Affairs in the East, Signed at Berlin, July 131878.

Treaty of Peace Between the Allied and Associated Powers and Bulgaria, and Protocol and Declaration signed at Neuilly-sur-Seine, 27 November 1919.

Zakon za trudowata powinnost, „Dyrżawen Westnik” 1920, nr 56.

51 К. Манчев, Парламентарната демокращия в България, [w:] 681-1948. Из историята на българската народност и държава, Софиа 1993, s. 265-270.

52 Ibidem, s. 269. 


\section{PIŚMIENNICTWO}

Awramow R., Stopanskijat XX wek na Bytgarija, Centyr za liberalni strategii, Sofija 2001.

Berow L., Protekcionizym na Balkanite predi Wtorata swetowna wojna, [w:] Protekcionizym i konkurencija na Balkanite prez XX wek, red. L. Berow, Byłgarska Akademija na Naukite, Sofija 1989.

Cankow A., Bytgarija w burno wreme. Spomeni, Prozorec, Sofija 1998.

Crampton R., Modernization: Conscious, Unconscious and Irrational, [w:] Industrialisierung und gesselschaftlicher Wandel in Südosteuropa, red. R. Schoenfeld, Südosteuropa-Gesellschaft, München 1989.

Cwetkow P., Poppetrow N., Kym mitoligijata na politiczesko razwitie na Bytgarija prez 30-te godini, „Istoriczeski Pregled” 1990, nr 2.

Dimitrow I., Knjazyt, konstitucijata i narodyt, Oteczestwen Front, Sofija 1972.

Dymarski M., Kształtowanie się systemu politycznego Serbii i Butgarii w XIX i pierwszych latach XX wieku, [w:] Prace Komisji Środkowoeuropejskiej PAU, t. XVIII, red. J. Machnik, I. Stawowy-Kawka, Wydawnictwo PAU, Kraków 2010.

Galunow T., Tretijat dyrżawen dys (1921-1923), „Istoriczeski Pregled” 1996, nr 5.

Genczew N., Oczerci. Socialno-psichologiczeski mitowe $w$ bytgarskata istorija, Septemwri, Sofija 2011.

Genowski M., Aleksandyr Stambolijski - otblizo i otdaleko, Izdatelstwo BZNS, Sofija 1982.

Griszina R., Wozniknowenie faszizma 1919-1925, Byłgarska Akademija na Naukite, Sofija 1976.

Kacarow K., Szesdeset godini żiwjana istorija, Prozorec, Sofija 1970.

Kazasow D., Widjano i preżwidjano 1891-1944, Oteczestwen Front, Sofija 1969.

Kalinowa E., Baewa I., Socializmyt w ogledaloto na prehoda, Iztok-Zapad, Sofija 2011.

Manczew K., Parlamentarnata demokracija w Bytgarija, [w:] 681-1948. Iz istorijata na bytgarskata narodnost i dyrżawa, Pelikan-Alfa, Sofija 1993.

Nedew N., Prekysnatost ili neprekysnatost na faszistkata diktatura w Bytgarija (1923-1944), „Istoriczeski Pregled” 1989, nr 8.

Palangurski M., Dyrżawno-politiczeskata sistema na Bytgarija (1879-1919), Słowo, Weliko Tyrnowo 1995.

Paleszutski K., Makedonskoto oswoboditelno dwiżenie sled Pyrwata swetowna wojna 1918-1924, Byłgarska Akademija na Naukite, Sofija 1993.

Petrowa D., Bytgarskijat zemedelski naroden syjuz 1899-1944, Fondacija „Detelina”, Sofija 1999.

Popow S., Bezsynici, Letopisi, Sofija 1992.

Statelowa E., Grynczarow S., Istorija na nowa Bytgarija 1879-1944, Anubis, Sofija 2004.

Tanty M., Bałkany w XX wieku. Dzieje polityczne, Książka i Wiedza, Warszawa 2003.

Welew A., Glawni reformi na zemedelskoto prawitelstwo, Nauka i Izkustwo, Sofija 1977.

Znamierowska-Rakk E., Bułgarski rewizjonizm terytorialny a zbliżenie z III Rzesza, „Studia z Dziejów Rosji i Europy Środkowo-Wschodniej” 2009, t. XLIV. 